\title{
Poverty Alleviation in China: The Rise of State- Sponsored Corporate Paternalism
}

\section{Camille Boullenois}

\section{OpenEdition}

\section{Journals}

Electronic version

URL: https://journals.openedition.org/chinaperspectives/10456

DOI: 10.4000/chinaperspectives. 10456

ISSN: 1996-4617

\section{Publisher}

Centre d'étude français sur la Chine contemporaine

Printed version

Date of publication: 1 September 2020

Number of pages: $47-56$

ISSN: 2070-3449

\section{Electronic reference}

Camille Boullenois, "Poverty Alleviation in China: The Rise of State-Sponsored Corporate Paternalism", China Perspectives [Online], 2020-3 | 2020, Online since 01 September 2021, connection on 10 December 2021. URL: http://journals.openedition.org/chinaperspectives/10456 ; DOI: https://doi.org/ 10.4000/chinaperspectives. 10456 


\section{Poverty Alleviation in China: The Rise of State-sponsored Corporate Paternalism}

CAMILLE BOULLENOIS

ABSTRACT: Since taking office, president Xi Jinping's government has granted massive funding to what has become China's strongest poverty-reduction campaign ever. Based on the study of detailed budgets in eight rural counties, as well as ethnographic and interview data in a ninth county, this article explores how poverty alleviation programs shape the distribution of power and resources in rural China. It argues that poverty alleviation in rural China predominately focuses on infrastructure investment and support to the local economy, rather than on social insurance, education, and household subsidies. Support to local companies, the article argues, entails coopting established enterprises, rather than supporting new entrepreneurship among poor households. Overall, the Chinese approach to rural poverty alleviation highlights the emergence of a state-sponsored corporate paternalism that strengthens local hierarchies of wealth and power.

KEYWORDS: Poverty alleviation, paternalism, public welfare, rural China.

\section{Introduction}

Wiping out poverty by 2020 has been one of the Chinese Communist Party's (CCP) top policy priorities. Since taking office, president Xi Jinping's government has granted massive funding to what has become China's strongest poverty-reduction campaign ever. Official statistics show that poverty reduction funds allocated by the central budget more than doubled between 2012 and 2018, with a particularly notable jump in 2016 and 2017 (Figure 1).

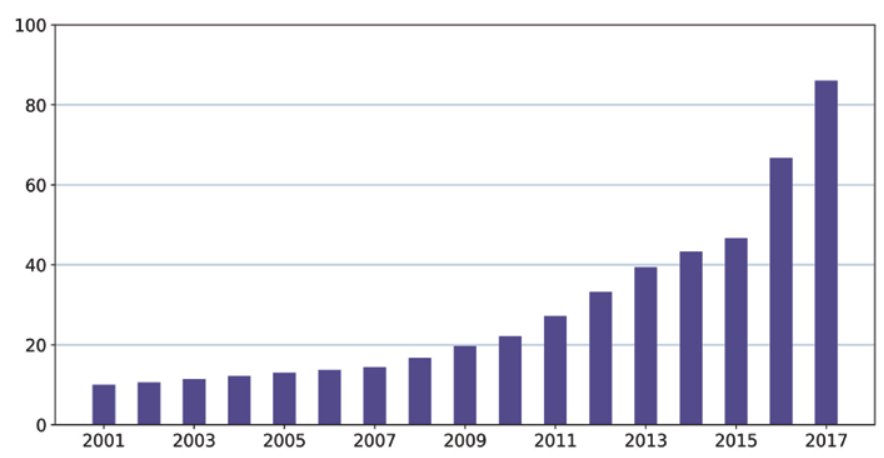

Figure 1. Poverty reduction funds allocated from the central budget (billion renminbi).

Source: Central budget and final accounts Public Platform.

http://www.mof.gov.cn/zyyjsgkpt/zyddfzyzf/zfxjjzyzf/

But the impact of these policies on social hierarchies has been seldom discussed. This article bridges this gap, first of all by examining the allocation of poverty funds by eight rural county governments under the $\mathrm{Xi}$ administration, and secondly by examining the impact of poverty alleviation discourse and policies on social hierarchies in a ninth rural county.

\section{Theory and literature review}

This article examines how the approach and priorities of local governments in allocating poverty alleviation funds shapes the distribution of power and resources at the local level.

Poverty, and the policies intended to reduce poverty, are inherently political because they touch upon the distribution of resources and the issue of "who gets what, when and how" (Lasswell 1936). They are also political because they touch upon moral understandings of who is a socially worthy individual and why. Whether poverty is seen as something one should be proud of, as in Maoist China, or something shameful, as in most contemporary societies, these different perspectives have a profound impact on social hierarchies (Yang, Walker, and Xie 2019).

These simple considerations have long been obscured in mainstream academic literature because, as anthropologist James Ferguson (1994) lamented, much of the scholarship on poverty has depoliticised questions of resource allocation. Embedded in the conceptual apparatus of "development" theories, the focus of developmental studies has remained largely "technical and managerial." These studies tried to understand what policies worked or failed and why, but usually did not question what "working" meant, or what were the impacts on social hierarchies and power relations.

Part of the academic literature has nonetheless sought to explore the political implications of public approaches to poverty (Bernstein 1977; Heyer, Robert, and Williams 1981; Galli et al. 1981; Ferguson 1994). Following a constructivist approach rather than a positivist or a structuralist framework,

\footnotetext{
1. In the central budgets, these numbers represent the poverty alleviation funds given by the central government to local governments (中央財政補助地方專項扶貧資金 Zhongyang caizheng buzhu difang zhuanxiang fupin zijin).
} 
these studies focused on the impact of development work on the distribution of power and resources, worldview, and perceptions (Ferguson 1994).

Few studies of poverty alleviation in China, so far, have benefited from this approach, though the sheer intensity of Chinese poverty alleviation policies makes it a very interesting case study. Poverty alleviation policies constitute a major focus of public action and condense a large part of the public budget. In Henan's X County, one of the counties studied in this paper, special poverty alleviation funds amounted to 273 million yuan in 2018 , slightly more than local government revenues coming from taxation (272 million yuan) and from general non-taxation sources (97 million yuan). ${ }^{2}$ As a result, the way these funds are distributed has important consequences on social stratification locally.

Poverty in China has long been highly political. Chinese leaders fear that poverty contributes to social instability and reduces the regime's legitimacy (Duckett and Wang 2015: 26). Nonetheless, the Chinese discourse on poverty has been increasingly framed as a scientific, rather than a political issue. As a case in point, the Third Plenary Session of the $18^{\text {th }}$ CCP Central Committee in 2013 proposed the formation of a "scientific and effective social governance system" that would "scientifically implement poverty alleviation management." Mun Young Cho's study of the dibao (低保, minimum livelihood guarantee) in China illustrates the shift towards a more numerical, economic, and scientific rationality (Cho 2010).

This shift has occurred progressively since the market reforms of the 1980s, and the welfare system that emerged was fragmented and deeply unequal, with serious regional imbalances (Carrillo and Duckett 2011). In the 1980s and 1990s, the most prominent approach to poverty alleviation in China was, as Wu Guobao argued, "a trickle-down regional economic development strategy, in which the income growth of poor households is expected to be realised via regional economic development" (Wu 1997).

But growth-led poverty alleviation policies failed to effectively reduce poverty because they support well-connected and large projects instead of small producers. According to Duckett and Wang (2015), such growthled poverty alleviation policies were undermined by the commodification and privatisation of welfare during the 1990s. In addition, Park, Wang, and $\mathrm{Wu}$ (2002) showed that problems in selecting the recipients of poverty alleviation funding led to little actual impact on poverty.

Comparing two Chinese provinces, Donaldson (2011) also found that the large infrastructure and industry development projects were less effective than micro-projects in alleviating poverty. In another study, Shenggen Fan and Connie Chang-Kang (2006) explained that the Chinese government's focus on intercity highways was not as effective in reducing poverty as the construction of lower-quality roads in remote areas would be. According to Jonathan Unger (2003), credit meant to assist the poor went instead to enterprises, in the belief that they would provide jobs. Ben Hillman (2003) also argued that health and education stagnated, as infrastructure and industrial growth were prioritised.

In the early 2000s, rising inequality and social instability led to another policy shift, towards more inclusive growth and more redistribution (Ngok and Huang 2014). Several nationwide social insurance schemes were rolled out and progressively included migrant workers and rural residents. The 2000s were also characterised by tax reforms benefiting the rural poor, and by increases in poverty alleviation funds. Overall, however, although great strides were made in reducing poverty, rural welfare has remained minimal and regressive (Gao et al. 2013), and subsidised loans have not always found their way into the hands of poor people (Fan, Zhang, and Zhang 2002).

The dibao, in particular, became one of the major pillars of poverty reduction in China, but its conceptualisation and implementation changed over time. Originally thought of as a way to support laid-off workers during the transition to the market economy, the program was then redirected towards prioritising aid to the old, the sick, and people unable to work (Cho 2010; Gao 2017; Solinger 2017). As Yang, Walker, and Xie (2019) showed, this re-targeting of dibao programs has diminished the stigma associated with being taken care of by the state, but it has also limited the program's ability to significantly reduce poverty. Overall, the extant literature shows that the dibao makes a significant difference in the poverty of its recipients, but has a very small effect on overall poverty (Chen, Ravallion, and Wang 2006; Shi Li and Sui Yang 2009; Golan, Sicular, and Umapathi 2015).

Since coming to power in 2013, Xi Jinping's government has been credited by analysts with several innovations in poverty alleviation approaches. First, the "precision poverty alleviation" (jingzhun fupin 精準扶貧) approach aims to target poor households rather than whole villages, and to create custommade projects adapted to their needs, in order to allocate funds more accurately. Second, in line with Xi's focus on eradicating corruption and the misallocation of funds, the government has sought to increase and better supervise the role of Party institutions in village-level poverty alleviation (Tan 2018). Poverty alleviation criteria were established on which officials are evaluated, alongside established criteria such as GDP (Gross Domestic Product) and social stability.

However, since Xi Jinping came to power, little research has provided a comprehensive overview of the poverty alleviation approach followed by the Chinese government. In addition, very little research has paid attention to the impact of poverty alleviation policies on social hierarchies and the respective roles of different social groups on the ground.

The article seeks to bridge this gap by exploring how poverty alleviation approaches in rural China shape the distribution of power and resources at the local level. It argues that the "trickle-down" approach to poverty alleviation, which repeats 1990s growth-led patterns of poverty alleviation, results in strengthening local hierarchies of wealth and power and consolidating a new social elite group in the countryside.

\section{Data and methods}

Three types of data were used: poverty alleviation budgets of eight counties, interviews in a ninth county, and official documents and articles. First, the research is based on a detailed study of poverty alleviation budgets published on local government websites in eight poverty-stricken counties. The county is a relevant spatial division since this "level of government is primarily responsible for delivering public services, managing local state-owned enterprises, and coordinating the economy" (Hillman 2010). In May 2019, according to the Chinese government website, there were 570 counties identified nationwide in China that received special central funding to fight poverty alleviation.

The counties chosen here are from three different areas:

- Guizhou Province. Per capita GDP in 2018: 41,244 yuan. ${ }^{3}$ Daozhen, Pan, and Puding counties. Guizhou is a poor province by Chinese standards, and in 2019 it hosted 47 poverty-stricken counties, among the most numerous in China.

- Henan Province. Per capita GDP in 2018: 50,152 yuan. Sui, Fengqiu, and Xichuan counties, and X County. Henan's economy is among the least economically developed in China, although the province is one of the most populated.

- Jilin and Heilongjiang Provinces. Per capita GDP in 2018: 55,611 yuan and 43,274 yuan, respectively. Antu and Gannan counties. Jilin and

2. Statistics compiled by author based on official budget figures from the Chinese government.

3. All GDP estimates come from World Bank data from 2019. 
Heilongjiang represent the old industrial north, with a traditionally stronger economy but an impoverished population. They have a few poverty-stricken counties.

Not all counties have published detailed poverty alleviation budgets online. The counties surveyed in this article were mainly chosen for the availability of such information. ${ }^{4}$ Different counties, especially in different provinces, also use varying categories and appellations for funding items. For instance, some budgets put environmental projects in the "infrastructure" category, while other budgets have a separate "environmental" category. As a result, I had to modify existing categories in order to make the budgets comparable. Likewise, the timeframes are not exactly the same. In two counties (Daozhen and Pan), budgets covered the $13^{\text {th }}$ Five-Year Plan, and in two counties (Puding and Gannan), budgets covered the years 2018 to 2020; while the other counties covered respectively 2018 (Fengqiu and Antu), 2019 (Sui), and a provisional budget 2020 (Xichuan). As I studied proportions of funding within each budget, this discrepancy did not make comparison impossible. ${ }^{5}$

The second type of data on which the article is based is a set of interviews with ten recipients of industry poverty alleviation funding in 2018 and 2019 in a ninth county in Henan: $X$ County, unidentified because of the sensitive content of my interviews. Like the other two Henan counties cited previously, $X$ is part of the national poverty alleviation program, and is an important part of the Central Plains Economic Zone. Interviewees were asked about their motivations to be part of poverty alleviation programs, about their perceptions of the local state's poverty alleviation work, as well as the implementation of these programs and the impact on their businesses. Interviews were analysed using qualitative methods and were used to provide insights into the perceptions of poverty alleviation programs by their local participants.

Last, I have drawn on a wide range of official documents published on government websites, and on local newspaper articles, which provide insights into the implementation of poverty alleviation policies, and into the different arguments and sensitivities relating to poverty alleviation among the central leadership and the local government. In particular, I reviewed all available newspaper articles and officials documents related to industrypoverty alleviation since 2014 in the nine relevant counties.

The combination of ethnographic and quantitative data, as well as textual material, provides crucial insights into the official and popular discourse on poverty, as well as the impact of poverty alleviation policies on social hierarchies.

The article proceeds as follows. The first part, based on comparative analysis of poverty alleviation budgets and official documents, shows that local governments use a "trickle-down" approach to poverty alleviation, by focusing on infrastructure spending and economic growth rather than direct financial transfers and social insurance provision to poor households. The second part, based on interviews and ethnographic data gathered in X County in Henan, shows that both the local state and local companies are the major beneficiaries of this approach, which strengthens local hierarchies of wealth and power and consolidates a new social elite group in the countryside.

\section{A "trickle down" strategy}

This section examines the allocation of poverty alleviation funds in eight rural counties and provides evidence that local governments allocate funds to infrastructure development and economic growth, rather than direct financial transfers and social insurance (Figure 2). It highlights a marketoriented approach to poverty alleviation that relies on trickle-down effects, reproducing patterns that China experimented with in the 1990s.

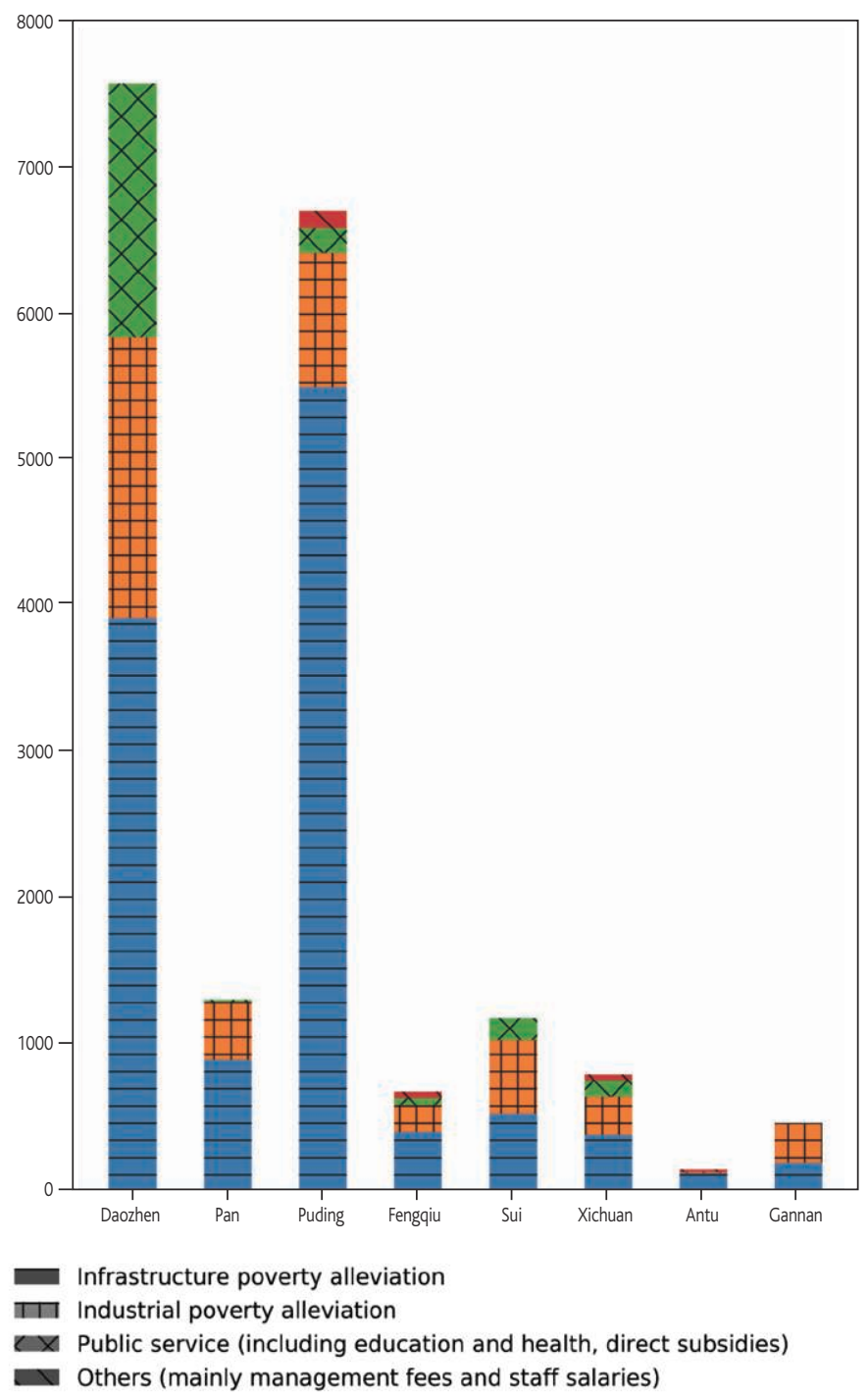

Figure 2. Allocation of poverty alleviation funds by sector (million RMB).

Source: County-level official documents about poverty alleviation projects.

\section{"If you want to get rich, build roads first"}

The well-known Chinese saying "If you want to get rich, build roads first" $^{\prime \prime}$ is particularly illustrative of rural China's poverty alleviation approach. The lion's share of poverty alleviation funding is devoted to infrastructure spending, and in particular to the construction of roads and bridges (Figure 3). ${ }^{7}$

The integration of rural road improvements within poverty alleviation projects dates at least back to the period 1995-1998, when a "Roads Improvement for Poverty Alleviation" (RIPA) project was implemented with the assistance of the World Bank (Hajj and Pendakur 2000).

4. This may limit the generalisation of findings, to the extent that counties that have not published data online may have different patterns of funds allocation from counties that have.

5. The budgets were all downloaded in May 2019 from local government websites. The links have since been deleted. Here is the link to a depository where all excel files can be downloaded: https://gitlab.com/cboullenois/poverty-alleviation-budgets-china-2019 (accessed on 15 March 2020)

6. Yao xiang fu xian xiu lu 要想富先修路.

7. Infrastructure refers to explicit categories labelled as such in the budgets, as well as items (housing infrastructure, environment projects and photovoltaic energy, and the construction of schools and clinics) that were labelled separately in some budgets. 


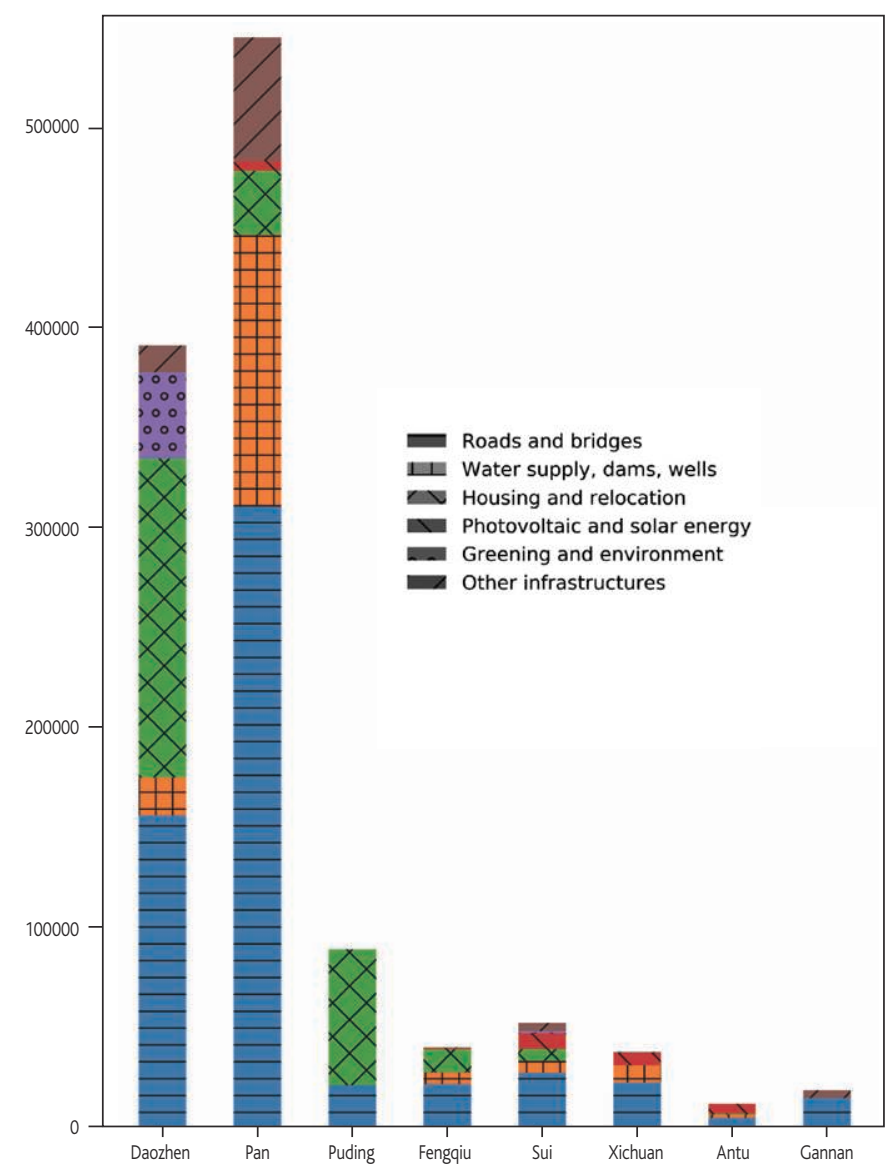

Figure 3. Allocation of infrastructure poverty alleviation funds (RMB).

In recent years, the central government has renewed its efforts to build rural roads. From 2013 to 2018, China has built and renovated 1.28 million $\mathrm{km}$ of rural roads in an effort to eliminate poverty. According to the Chinese news outlet Xinhua, this infrastructure effort is deemed essential to eliminating the physical isolation of remote villages, and integrating their members into the country's social and economic life. ${ }^{8}$

The budgets give further details about the types of roads built under poverty alleviation projects. They are mostly local and serve towns and villages. In Gannan County, for example, all road projects are concrete fourgrade roads (the lowest road grade of the Chinese classification, usually characterised by limited road width and low quality) of 160, 120, 94.36, and $57.14 \mathrm{~km}$, respectively. In other counties, projects are even smaller and more local: in Daozhen County, for example, out of 573 road construction projects, only 18 are longer than ten kilometres. Most connect villages to neighbouring villages, or groups of houses within villages.

In addition to roads and bridges, local governments dedicate funding to housing and village infrastructure projects, which mainly include construction of "middle-class" (xiaokang 小康) housing, renovation of old houses, and the improvement of public infrastructure in residential communities. But Pan County, in Guizhou, is the only surveyed county with more than $50 \%$ of the infrastructure budget dedicated to housing and village infrastructure (arguably, because Pan County's budget includes "villagers self-funding" for housing).

Although widely publicised, in most surveyed counties, relocation projects are also a minor part of the surveyed poverty alleviation budgets. Only in Daozhen County do relocations amount to a significative proportion of housing projects.

The third largest item that stands out in poverty alleviation infrastructure is investment in photovoltaic systems. In three counties (two in Henan and one in jilin) out of the eight surveyed, this makes up more than $15 \%$ of the infrastructure budget, and in one case (Antu County in jilin), more than $40 \%$. This accent on solar energy is in line with the central government's strategy, announced in 2014, to alleviate rural poverty and reduce the solar energy industry's overcapacity by deploying photovoltaic systems (Geall et al. 2017).

\section{Helping companies boost the local economy}

Behind investment in infrastructure, the second largest part of the rural poverty alleviation budgets is "industry poverty alleviation" (chanye fupin 產業扶貧), which makes up more than $25 \%$ in five out of eight case-study counties, and more than $40 \%$ in two cases. $^{9}$

Policies based on supporting major businesses to boost the local economy in poor regions constituted one of the main poverty alleviation approaches in the 1990s. Under the name of "industry poverty alleviation," this approach has also been part and parcel of poverty alleviation since the inception of the "targeted poverty alleviation" plan by Chinese president Xi jinping in 2013.

Fengqiu county's budget, in Henan, gives a relatively detailed account of the industry poverty alleviation program (Figure 4). Among the biggest items in this category, "subsidies and infrastructure construction for employment bases", "investment in the collective economy" and "subsidies to private limited liability corporations" stand out. As the following section will show, funding under these items is largely distributed to existing local enterprises.

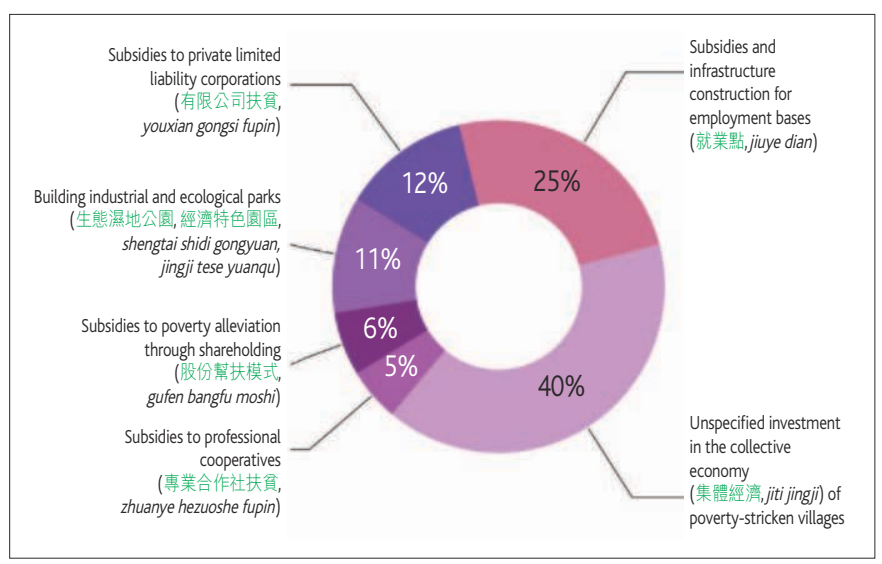

Figure 4. Fengqiu County government, allocation of industry poverty alleviation budget in Fengqiu County.

Source: 2018 County-level poverty alleviation projects in Fengqiu County.

A close examination of media reports and official documents in the other surveyed counties suggests a similar emphasis on corporate actors and cooperatives.

Overall, the budgets and local media reports in the eight survey counties suggest that local governments generally choose to support existing companies through subsidies and investment, rather than encouraging new entrepreneurship. This is consistent with the central government's discourse: under Xi Jinping's leadership, the government supports the largest enterprises in order to provoke a "trickle down" effect in the local population. According to this strategy, "The carriers for these policies are mostly key enterprises," as Kun Yan (2016) argued.

In Puding County in Guizhou, for example, an official document mentions that 46 tea industry production and processing enterprises in the county,

8. "China Focus: Rural roads important to poverty-relief in China," Xinhua, 15 January 2018, http:// www.xinhuanet.com/english/2018-01/15/c_136897242.htm (accessed on 12 July 2019).

9. Industry poverty alleviation corresponds to projects that were explicitly labelled as such in the budgets. 
including six provincial-level leading enterprises and 12 municipal-level leading enterprises, are involved in the project. ${ }^{10}$ In Daozhen County, a local news article explains: "Relying on leading enterprises [will] promote industrial growth" and it will also "lead the poor households to increase their income."

Sui County in Henan is the only surveyed county that mentions promoting entrepreneurship among the poor population. An official document describes the government's strategy to "help poor households with labour ability and willingness to develop a business to select quasi-industrial projects; guide poor households with no working ability and no willingness to develop a business to transfer their land contractual management rights."11 Cooperatives, family farms, and companies will be given subsidies and loans based on their ability to provide employment for poor households and returning migrants, the article explains.

The frequent emphasis on poor households' willingness to work shows that, for local governments, at least part of the problem of poverty is the result of poor mental dispositions of poor households. As an article mentions: "From the perspective of concrete practice, it is difficult for some poor people to eliminate their lazy habits." ${ }^{\prime 2}$ As a result, the government must rely on "ideological education" to encourage poor households to work in poverty alleviation workshops and increase their income (ibid.).

This argument hints at a paternalist approach to poverty alleviation, seeking to "bring discipline to the lives of the poor so that they can become competent actors who (...) recognise and act on their interests as freely choosing agents of the market" (Soss et al. 2009). Poor people are considered bad market actors who need incentives and coercion from the government to enforce rational and disciplined behaviour.

\section{From "social assistance" to a "self-help" approach}

In contrast to infrastructure spending and subsidies to enterprises, the surveyed budgets are characterised by a striking absence of direct financial help, subsidies to poor households, and living allowances.

Only in one case (Daozhen County) do funds allocated to "public services" represent more than $20 \%$ of expenditure, and in three cases (Sui, Xichuan, and Fengqiu) more than $5 \% .{ }^{13}$ What is more, even within this category, the amounts actually reserved for subsidies to poor households appear even sparser, while the vast majority of "public services" funding is used for building health and education infrastructure.

In Daozhen, for example, $86 \%$ of public services funds are dedicated to building and renovating schools (44\%), constructing health centres (40\%), and cultural centres (2\%). Only $14 \%$ is dedicated to subsidies for poor households: $7 \%$ in the form of social insurance, and $7 \%$ in the form of subsidies and allowances. This small amount of the budget, according to local newspapers, allows for preschool, primary, and secondary education subsidies, as well as health subsidies and compensation for major illness insurance. ${ }^{14}$

Sui County stands out, with a more significant commitment to direct subsidies to poor households. Health subsidies make up $37 \%$ of the public services budget, providing basic medical insurance premium reduction and free medical examination, in addition to $6 \%$ of the budget dedicated to supporting poor elderly people. Another $12 \%$ of the budget is reserved for creating "public welfare jobs" such as cleaning professions, and $11 \%$ to education subsidies. These subsidies are reported to have helped 33,545 households in the county, providing skills training and student assistance, as well as pre-school education. ${ }^{15}$

Part of the explanation for the scarcity of direct financial help, subsidies to poor households, and living allowances, is that most of the direct financial help to poor households is given in the form of social insurance, in particular the "dibao," a minimum livelihood guarantee payment for people below the poverty line. Social insurance is usually not included in government budgets and has its own system of funding and expenditure.

However, there is evidence that funding for the dibao has begun to stagnate in the countryside and has decreased in urban areas (Solinger 2017). Part of that stagnation is explained by the falling number of recipients as absolute poverty diminishes in China.

In this regard, local budgets in the eight surveyed counties offer only scant data (in contrast to the abundance of data on poverty alleviation projects). In one case, however, Puding County in Guizhou, available data show the evolution of the budgets dedicated to the minimum livelihood guarantee for people below the poverty line. Since 2011, the number of local recipients of the rural dibao has steadily decreased. Despite the increase in the rural dibao standard (the amount received by each recipient per year), the total expenditure spent on rural dibao per year diminished between 2015 and 2017 (Figure 5). Although figures about the number of poor households in Puding County are unavailable, an article mentioned that the county had been removed from the list of poverty-stricken counties in April 2019. ${ }^{16}$

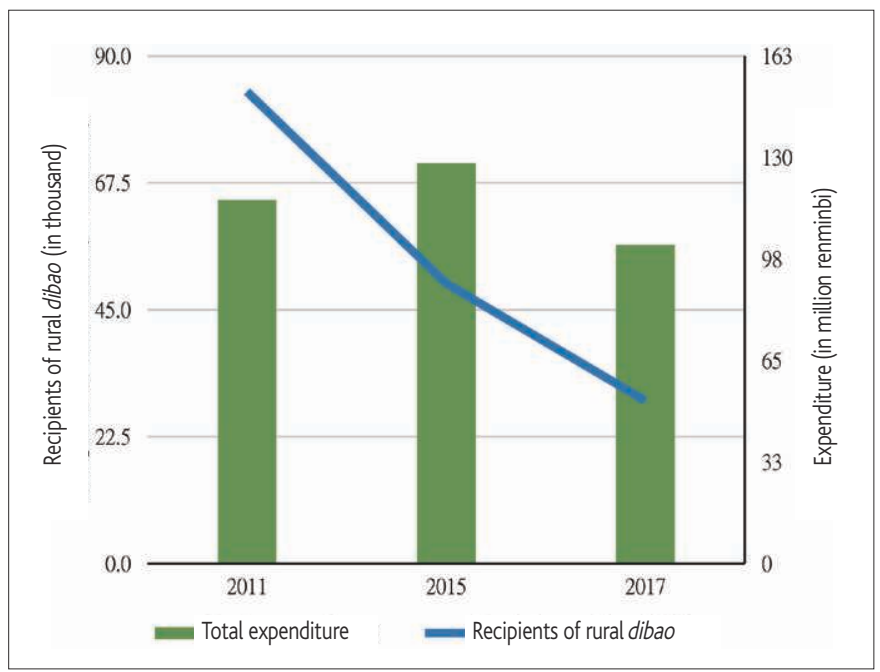

Figure 5. Rural dibao in Puding County.

10. “普定縣聚焦'四大主導產業'破解產業扶貧難題” (Puding xian jijiao 'si da zhudao chanye' pojie chanye fupin nanti, Puding County focuses on 'four big pillar industries' to solve industrial poverty alleviation difficulties), 普定縣全面小康辦 (Puding xian quanmian xiaokang ban, Puding County well-off society office), 26 December 2018, http://www.gzstjj.gov.cn/rdzt/xkdt/ jyjl/201812/t20181226_3721039.html (accessed on 12 July 2019).

11. “睢縣農業產業扶貧政策指導意見” (Sui xian nongye chanye fupin zhengce zhidao yijian, Sui County agricultural industrial poverty alleviation policy guiding opinions), Sui County government website, http://www.suixian.gov.cn/news/news_view.asp?newsid=18097 (accessed on 12 July 2019).

12. “浙川縣: 產業扶貧帶動就業扶貧助力脱貧” (Xichuan xian: chanye fupin daidong jiuye fupin zhuli tuopin, Luanchuan County: Industry poverty alleviation drives employment and helps poverty alleviation), Henan Provincial Office of Poverty Alleviation and Development website, 2 February 2019, http://www.hnsfpb.gov.cn/sitesources/hnsfpb/page_pc/gzdt/cyfp/ article30ee0c4d094b45009f1de3eaff624f44.html (accessed on 12 July 2019).

13. "Public services" refers to many diverse categories such as education, health, social insurances, subsidies to poor households, but also construction of schools and clinics.

14. “道真縣: ‘十二項扶貧工程'磼保1.3萬貧困人口脱貧” (Daozhen xian: 'shi er xiang fupin gongcheng' quebao 1.3 wan pinqiong renkou tuopin, Daozhen County: 12 poverty alleviation projects allow 13,000 people to be lifted out of poverty), People's Daily - Guizhou channel, 15 August 2017, http://www.guizhou.gov.cn/xwdt/mtkgz/201709/t20170927_1032486.html (accessed on 12 July 2019).

15. “河南睢縣: 教育扶貧為貧困學子保駕護航” (Henan Sui xian: jiaoyu fupin wei pinqiong xuezi baojia huhang, Henan Sui County: education poverty alleviation helps poor students), People's Daily - Henan channel, 13 November 2018, http://ha.people.com.cn/n2/2018/1113/c37839832281103.html (accessed on 12 July 2019).

16. “貴州省政府正式批准18個縣(區,市)退出貧困縣序列” (Guizhou sheng zhengfu zhengshi pizhun 18 ge xian (qu, shi) tuichu pinkun xian xulie), Guizhou Provincial Government officially approved the withdrawal of 18 counties (districts, cities) from the poverty-stricken counties), News.sina.com, April 2019, https://news.sina.com.cn/c/2019-04-25/doc-ihvhiqax4982715.shtml (accessed on 12 July 2019). 
The scarcity of direct financial help also illustrates a shift in poverty alleviation programs from a "social assistance" approach to a "self-help" approach, and from redistribution-based to market-based. According to Kun Yan (2016), this shift was first promoted in the 1990s. But a further shift towards economic growth and marketisation was concretised under Xi Jinping, promoting the idea of competitive activity and individual participation in the market. As a 2017 People's Daily article put it: "The introduction of market mechanisms and market forces to participate in poverty alleviation is an effective way to improve the accuracy and efficiency of poverty alleviation (...) The market approach is based on the autonomous decisionmaking and market transactions of the poor. ${ }^{117}$ The Chinese government turns away from charity and direct financial support to poor households, because giving directly to villagers is understood to run counter to the idea that poor people must become self-sufficient and enterprising.

This also implies that poverty is considered from the angle of temporary and residual problem-solving, rather than equity and redistribution, as illustrated by this news report: "After escaping from poverty, [poor people] no longer need the minimum living guarantee provided by the social safety net. From this perspective, the social safety net's protection of the poor is short-term and temporary." A long-term social safety net would "force the poor population into a passive position of accepting relief, and fail to spur enthusiasm for life and work." ${ }^{118}$

The Chinese approach to poverty alleviation reveals a strategy that seeks to orient individuals towards market-conforming behaviour. This approach also reproduces patterns that were observed in China in the 1990s, despite the drawbacks highlighted by scholars and which the Hu/Wen administration sought to address (Wu 1997; Park, Wang, and Wu 2002; Unger 2003; Hillman 2003; Shi, Luo, and Sicular 2011; Donaldson 2011; Duckett and Wang 2015).

\section{The rise of state-sponsored corporate paternalism}

What are the social and political consequences of this return to a growthled poverty alleviation approach for local communities? How is poverty alleviation perceived, used, and framed locally? The second part of this article, based on ethnographic and interview data in X County, explores the impact of poverty alleviation on the local distribution of power and resources. It highlights the central role of local company owners in poverty alleviation programs, and the emergence of a new state-sponsored corporate paternalism that is profoundly reshaping the local distribution of power and resources.

\section{Transformation of authority patterns: Entrepreneurs in charge of local welfare}

A poverty-stricken county on the banks of the Yellow River in Henan, $X$ County shows a similar pattern in its allocation of poverty alleviation funds to those studied in the eight other counties, as Figure 6 shows.

Like the other case-study counties, $X$ County has also adopted strategies that put local companies at the centre of poverty alleviation work. This is accomplished by funnelling funds to companies, which in turn are responsible for redistributing the funds and providing employment to poor households.

This strategy is implemented, first of all, under the form of 126 "employment bases" (jiuye jidi 就業基地), which employ, according to one local article, "more than 7,000 people [in X County] including nearly 3,000 people from poor households." Hong, a local entrepreneur in the wood business, explained that through this "poverty alleviation employment base"

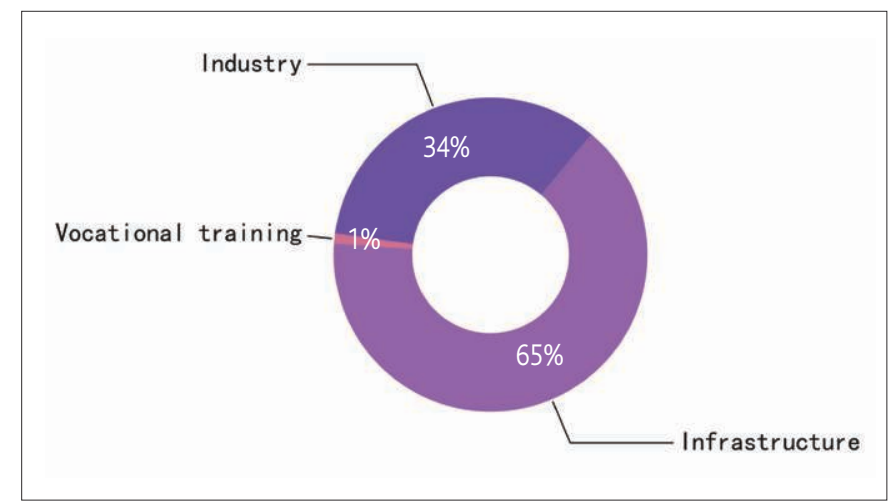

Figure 6. Allocation of poverty alleviation funds in X. County in 2018.

scheme, the local government provides enterprises with subsidies and loans, as long as they agree to hire workers from poor households. ${ }^{19}$

Another interviewee, a business owner in the same industry, provided more details about how the employment base scheme works:

The government helps companies with preferential measures. The government gives subsidies and funds to companies, and helps them take loans. Then, companies help the poor with [this] money [by providing employment]. This is what we call "companies lead workers out of poverty."${ }^{120}$

A second way industry poverty alleviation works in $X$ County is through shareholding cooperatives. Yue, the leader of an agricultural cooperative in $X$ County, explained that cooperatives must have a minimum of five members to register with the local government. He initially invested 4 million yuan in his cooperative, about $60 \%$ of the total investment, which gave him the power to make all decisions regarding the company. Today, 60 families participate in the cooperatives by providing their land and getting dividends in return.

The cooperative, Yue explained, is in fact like a shareholding company, but benefits from advantageous tax policies. This confirms findings from the scholarly literature. Farmers' cooperatives have experienced rapid expansion in the last two decades in China, encouraged by fiscal incentives and policy support (Deng et al. 2010). But field studies have shown that most of these agricultural cooperatives were shell cooperatives or de facto "commercial enterprises controlled by officials, business entrepreneurs, and merchants" ( $\mathrm{Hu}$ et al. 2017).

Now, Yue said, his cooperative is part of the poverty alleviation program. Over the last five years, the county has invested first 1.2 million then 0.96 million yuan in the cooperative. The cooperative, in turn, must transfer a fixed amount (1,000 yuan per year) to poor local households (about 200) in the form of dividends each year during the next five years:

17. “構建政府與市場協同發力的大扶貧格局” (Goujian zhengfu yu shichang xietong fali de da fupin geju, Building a pattern of great poverty alleviation in synergy between the government and the market), People's Daily, 19 June 2017, http://theory.people.com.cn/n1/2017/0619/ c40531-29346981.html (accessed on 15 March 2020).

18. “補精神之鉟, 添脱貧動力” (Bu jingshen zhi gai, tian tuopin dongli, Reinforce the spirit, boost the dynamism of poverty alleviation), People's Daily, 6 May 2018, http://opinion.people.com.cn/ n1/2018/0506/c1003-29966937.html (accessed on 12 July 2019).

19. Interview conducted in X County in August 2018.

20. Interview conducted in X County in April 2018. 
[Poor households] take the government's money to buy shares in my company. That money is given to them (...) In total, [they each invest] 8,000 RMB, and they can get 1,000 RMB of dividends each year. ${ }^{21}$

In both the employment-base scheme and the cooperative scheme, two mechanisms are at play: a trickle-down mechanism (boosting local companies will have positive results on the local poor population), and subsidies or dividends distributed to poor households who participate in employment or cooperative shareholding schemes.

In effect, by reaching poor households through the intermediary of companies, the local government pushes business owners into the crucial role of service providers and community leaders and lends them legitimacy as central actors of the poverty alleviation effort.

That legitimacy relies on a perception of society as naturally hierarchical, and of business owners as welfare providers. In this regard, industry poverty alleviation schemes accelerate the rise, observed by An Chen (2014), of new patterns of authority centred around business owners, allowing for a costeffective mode of local governance.

The legacy of a traditional Confucian model, with its "emphasis and acceptance of hierarchical structure" and on the "interdependence of human relations" (Leung and Nann 1995), may arguably also play a role in the reconstruction of local authority patterns centred around business owners. Such patterns bring back a tradition of Chinese welfare in which a gentry class, while "politically, economically and socially privileged, [was] also expected to undertake social responsibilities and to promote the wellbeing of ordinary people and serve the interests of their own communities" (Pan 2017).

The idea of placing welfare into entrepreneurs' hands also taps into widespread popular beliefs and narratives, inherited from the county's last decades of economic development, which present them as pioneers who lead fellow villagers out of poverty. As a local entrepreneur explained: "A business, in reality, is a social service enterprise. It can lead the nonemployed labour force (...) and give them a good life."22 This idea is also widespread among non-entrepreneurs in the county. A young self-employed man, for example, argued:

Wealthy entrepreneurs are successful because they were brave, audacious, industrious, and intelligent. If you support them, they will make the best of this opportunity and help the community develop. On the other hand, if you support poor people, they will waste their opportunities. $^{23}$

\section{Welfare funds captured by local entrepreneurs}

This poverty alleviation approach serves the business interests of the business owners who take part in poverty alleviation schemes.

Turning its back on previous policies that relied on relief money, and inspired by central policies, the county has now turned to companies to develop the local economy (...) What "industrial poverty support" actually supports are the two foundational industries of the county that were created from scratch. ${ }^{24}$

For many local businesses, this support is invaluable. Securing a labour force, paid for at least in part by the government, is a major advantage of participating in industry poverty alleviation schemes. Poverty alleviation policies also allow business owners to capture valuable funds and resources for their own interests. For example, although Hong took part in the scheme, she decided not to hire poor workers. She already has several workers who have been working in the factory for several years: "Most of these [poor] people are lazy, which is why they are poor. They do not want to work. Instead, they waste their time drinking or gossiping with neighbours. ${ }^{125}$

Hong told me that most company owners, like her, circumvented the policy by making poor households sign their names on a document but not hiring them. "Companies hire poor people only on paper," she said. "In fact, they prefer to hire good workers who are not necessarily poor."26

Loans and funding provided by the local government are also essential. For example, poverty alleviation funds have allowed Yue's cooperative to grow: "It brings money so that I can use it; isn't it a big help for me? It is capital, and with that capital I can invest in many projects." ${ }^{127}$

In addition, the tax cuts associated with poverty alleviation programs help local companies. Several interviewees have indicated that they hadn't paid any tax during the last few years: "Here, we pay basically no tax. You see, our factories receive lots of preferential policies because we are in a poverty-stricken county. ${ }^{128}$

\section{State co-optation and reinforcement of existing business hierarchies}

Poverty alleviation schemes also reinforce existing hierarchies by reinforcing the power of the already best-connected and best-performing companies.

Poverty alleviation policies supporting small entrepreneurs from poor households exist, but they are scarce. As part of a program led by the municipality, the county has put in place a policy to grant subsidies to 40 "self-employed poor people." One of these "self-employed poor people," Liu, told me his story. Liu had worked for ten years as a driver in a big city before coming back to his village. He was categorised as a "poor household" by his village committee. His is now among the twenty remaining "poor households" in a village that counts many successful entrepreneurs in the car parts industry.

Two years ago, Liu was approached by the committee, under the supervision of county and township officials. They categorised him as "capable of development" and offered him a subsidy of 8,000 yuan, as well as a 50,000 yuan loan from the bank. This was a fantastic opportunity, he said. He was able to buy several cows, raising their number from three to eight, and to modernise his farming installations. ${ }^{29}$

But such support for entrepreneurship on provided to poor households is marginal in the local state's poverty alleviation strategy. The scope and funding for self-employment pales in comparison with the scope and funding for established businesses. According to local budgets, in 2018, the funds dedicated to entrepreneurship represented less than $0.2 \%$ of the industry poverty alleviation funds. In addition, funding for self-employed

\footnotetext{
21. Interview conducted in X County in March 2019.

22. Interview conducted in X County in April 2018.

23. Interview conducted in X County in April 2018

24. Article published on X County's government website, 2017

25. Interview conducted in X County in August 2018.

26. Interview conducted in X County in August 2018

27. Interview conducted in X County in March 2019.

28. Interview conducted in X County in April 2018.

29. Interview conducted in X County in March 2019
} 
households is limited to agricultural self-employment, while support to established enterprises targets various agricultural and industrial sectors.

The county's "returning migrant workers entrepreneurship park" is a good illustration of this bias towards big businesses. Despite its name, the park mainly comprises big companies from outside the county - mostly from South China and Hong Kong - which have settled there to benefit from tax cuts and low wages. Other companies include X County's leading enterprises, but very few run by return migrant entrepreneurs and none by poor households.

Within the business community, the poverty alleviation programs also enforce the existing hierarchy by supporting the strongest and most connected local companies. Beneficiaries of subsidies, in practice, are often selected through close contacts with the local government.

Hong explained, for example, that companies must meet standards in size and in number of employees - in order to participate to industry poverty alleviation schemes. ${ }^{30} \mathrm{~A}$ further selection is then made among the selected companies, between those that do receive the subsidiaries, and those that do not. Although Hong was selected to participate to the industry poverty alleviation scheme, she never actually received the subsidies. All she got was 2,000 yuan to buy a big board saying "poverty alleviation employment base," which she stuck on the factory's wall. She blamed that failure on the local government's corruption. Only well-connected entrepreneurs, she said, could receive the subsidies the government had promised to give them. ${ }^{31}$

Another interviewee, Wang, explained that the local government planned to give the factory subsidies for participating to the poverty alleviation scheme, but Wang did not receive them, and "did not fight to get them." ${ }^{132}$

Yue, by contrast, obtained the poverty alleviation subsidies. The industry poverty alleviation program, Yue explained, is administered by the local county government finance department:

The application is instructed by the Finance Bureau (...) then it is approved by a panel of experts (...) at the township government level (...). The city must know how much money you will spend and how you will spend it (...) because the Finance Bureau cannot spend 1.2 million renminbi for no reason (...) and they can inspect [the cooperative].

Although he did not mention it, he himself likely benefited from his privileged position as a township official in order to obtain poverty alleviation funding. ${ }^{33}$

\section{Political patronage of businesses}

State support comes at a cost. The official discourse emphasises that it gives entrepreneurs a special responsibility to take on a central role in poverty alleviation. As leaders chosen and nurtured by the government, they have a debt towards both the local state and the local population:

Wang [a local entrepreneur] absorbed all of the twenty-three poor households in his village into his factory. He said: "As a person, I must know how to be grateful. This factory was built by the government. I must repay society. ${ }^{34}$

The co-optation and the flow of funding and subsidies that comes with state support also enable the government to secure a strong control of business actors. These measures also feed into perceptions of business actors as unable to function without government help. The local official media contribute to such perceptions. A local article mentions that in one company, after having built a new workshop and bought new equipment, "the operating capital was stretched and the company in dire difficulties. Fortunately, the township coordinated 500,000 yuan of poverty alleviation loans to cover its urgent need." Industry poverty alleviation schemes thus entrench local officials as the most prominent holders of local power, and encourage strong interventionist policies on their part.

While benefiting companies, poverty alleviation schemes also increase their dependency on the local government, and subject business owners to continuing support from the state. In the long run, entrepreneurs themselves have observed that local state support distorts the market and maintains companies that would have otherwise collapsed.

As a result, not all local entrepreneurs were enthusiastic about participating in state-led poverty alleviation programs. One entrepreneur, for example, explained why he refused to take the government's poverty alleviation subsidies:

We don't want to accept government subsidies (...) We feel more comfortable earning our own money (...) There is no free lunch in the world. If you take this money, you will be very tired, the government will make visits, will give you subsidies according to projects, depending on if you want to expand [your business]. ${ }^{35}$

The corporate paternalism that local governments encourage also runs contrary to some entrepreneurs' ideas and expectations about their role in society. Some interviewees challenged the idea that entrepreneurs should be welfare providers. Wang, for example, explained: "They also require us [to help], but I think that, as long as [the government] distributes the poverty alleviation money to workers, we don't need to do that. ${ }^{136}$ To him, the main responsibility of companies is to perform well in order to boost the local economy and provide jobs. Like several other interviewees, he does not fully agree with the ideal of corporate paternalism encouraged by the local state.

\section{Conclusion}

The article has argued that poverty alleviation in rural China predominately focuses on infrastructure investment and support to the local economy, rather than on social insurance, education, and household subsidies. Support to local companies, the article argues, entails co-opting established enterprises, rather than supporting new entrepreneurship among poor households. Overall, the Chinese approach to rural poverty alleviation highlights the emergence of a state-sponsored corporate paternalism that strengthens local hierarchies of wealth and power.

This approach to poverty alleviation is not redistributive in that it does not intend to challenge or alleviate current social inequalities and does not target poor households. As the All-China Federation of Industry and Commerce puts it, this approach promotes the "great ideal of first

\footnotetext{
30. Interview conducted in X County in August 2018.

31. Interview conducted in X County in August 2018

32. Interview conducted in X County in April 2018.

33. Interview conducted in X County in March 2019.

34. Article published on X County's government website, 2018

35. Interview conducted in X County in April 2018.

36. Interview conducted in X County in April 2018.
} 
benefiting the rich, and finally achieving common prosperity." ${ }^{137}$ Overall, this approach does not bode well for long-term poverty reduction in China, since researchers largely pointed out that it increased inequality while not efficiently reducing poverty (Unger 2003; Hillman 2003; Shenggen Fan and Connie Chang-Kang 2006; Donaldson 2011).

This approach, moreover, is undergirded by a local official discourse that is essentially market-oriented and considers poor people either lazy and unwilling to work; or sick and unable to work. For the former category of poor people, the official discourse calls for forcibly integrating them into the market economy. Only poor people in the latter case are considered an acceptable target of state-sponsored welfare.

All in all, this approach resembles the neoliberal perspectives identified, in other contexts by Ferguson (1994) and Harvey (2007), where market dynamics are considered the central mechanism for governance and welfare, and where business-friendly policies are adopted in the belief that they will trickle down to the poor. But the Chinese discourse and policies differ from these neoliberal perspectives in that companies and company owners are forced to play an active role in poverty alleviation. While the approach to poverty reduction follows a trickle-down principle, the state actively seeks to make the trickle-down process work by forcing companies to play a role in alleviating poverty.

This has many important implications. On the one hand, this approach marks the rise of a new type of state-sponsored corporate paternalism, intended to coax local business owners into becoming service providers and community leaders. This, in turn, accentuates patterns of authority and power centred around business owners and local governments.
On the other hand, however, the case of $X$ County shows that local business owners are divided in their reactions to state-sponsored corporate paternalism. Among the local business community, two types of discourse coexist. One sees business owners as natural social leaders and responsible for the well-being of their local community. The other, on the contrary, considers individuals as self-reliant in the market economy and does not give business owners a role in ensuring the welfare of their community. Due to these mixed reactions, it is still uncertain whether the current Chinese administration, which has chosen to strongly support corporate paternalism and to enhance the social role of business owners, will manage to impose this approach onto local communities.

I Camille Boullenois is a sociologist and China expert trained at Sciences Po, Oxford, and the Australian National University. She now works as a consultant at Sinolytics in Berlin, Pasteurstrasse 8, 10407 Berlin, Germany (camille.boullenois@gmail.com).

\section{Manuscript received on 14 July 2019. Accepted on 4 March 2020.}

37. “高雲龍同志在全國'萬企幫萬村'精準扶貧行動先進民營企業表彰大會暨扶貧日論壇 上的講話" (Gao Yunlong tongzhi zai quanguo 'wan qi bang wan cun' jingzhun fupin xingdong xianjin minying qiye biaozhang dahui ji fupin ri luntan shang de jianghua, Comrade Gao Yunlong's speech at the National '10,000 Enterprise help 10,000 villages' Precise poverty Alleviation Action Advanced Private Enterprise Awards Conference, at the Poverty Alleviation Day Forum), AllChina Federation of Industry and Commerce website, 16 October 2018, http://www.acfic.org.cn/ wqbwc/djh/201811/t20181107_69523.html (accessed on 12 July 2019).

\section{References}

CARRILLO, Beatriz, and Jane DUCKETT (eds.). 2011. China's Changing Welfare Mix: Local Perspectives. London and New York: Taylor \& Francis.

CARRILLO, Beatriz, Johanna HOOD, and P.I. KADETZ (eds.). 2017. Handbook of Welfare in China. Cheltenham, UK; Northampton, MA, USA: Edward Elgar Publishing.

CHEN, An. 2014. The Transformation of Governance in Rural China: Market, Finance, and Political Authority. Cambridge: Cambridge University Press.

CHEN, Shaohua, Martin RAVAILLON, and Youjuan WANG. 2006. "Di bao: A Guaranteed Minimum Income in China's Cities?" Policy, Research working paper, no. WPS 3805. Washington, DC: World Bank.

CHO, Mun Young. 2010. "On the Edge Between 'the People' and 'the Population': Ethnographic Research on the Minimum Livelihood Guarantee." The China Quarterly 201: 20-37.

DENG, Hengshan, Jikun HUANG, Zhigang XU, and Scott ROZELLE. 2010. "Policy Support and Emerging Farmer Professional Cooperatives in Rural China." China Economic Review 21(4): 495-507.

DONALDSON, John A. 2011. Small Works: Poverty and Economic Development in Southwestern China. Ithaca and London: Cornell University Press.
DUCKETT, Jane, and Guohui WANG. 2015. "Poverty and Inequality." In Jacques de Lisle and Avery Goldstein (eds.), China's Challenges. Philadelphia: University of Pennsylvania Press. 25-41.

FERGUSON, James. 1994. The Anti-politics Machine: 'Development', Depoliticisation and Bureaucratic Power in Lesotho. Minneapolis, London: University of Minnesota Press.

FAN, Shenggen, and Connie CHAN-KANG. 2006. Road development. Economic Growth and Poverty Reduction in China. IFPRI Research Report: 138.

FAN, Shenggen, Linxiu ZHANG, and Xiaobo ZHANG. 2002. Growth, Inequality, and Poverty in Rural China: The Role of Public Investments. Vol. 125. Intl Food Policy Res Inst.

GALLI, Rosemary. 1981. Political Economy of Rural Development. Albany, New York: Suny Press.

GAO, Qin, Sui YANG, and Shi LI. 2013. "The Chinese Welfare State in Transition: 1988-2007." Journal of Social Policy 42(4): 743-62.

GAO, Qin. 2017. Welfare, Work, and Poverty: Social Assistance in China. New York: Oxford University Press.

GOLAN, Jennifer, Terry SICULAR, and Nithin UMAPATHI. 2015. "Unconditional Cash Transfers in China: an Analysis of the Rural Minimum Living Standard Guarantee Program." Policy Research working paper, no. WPS 7374. Washington, D.C.:World Bank Group. 
GEALL, Sam, and Wei SHEN. 2017. "Solar PV and Poverty Alleviation in China: Rhetoric and Reality." STEPS Working Paper 93. Brighton: STEPS Centre.

HACKER, Jacob S. 2002. The Divided Welfare State: The Battle over Public and Private Social Benefits in the United States. New York: Cambridge University Press.

HAJJ, Hatim, and V. Setty PENDAKUR. 2000. "Roads Improvement for Poverty Alleviation in China." East Asia Region Transport Sector (EASTR) working paper, no. 1 Washington. D.C.:World Bank Group.

HARRISS, John. 2009. Bringing Politics Back into Poverty Analysis. Oxford: Oxford University Press.

HARVEY, David. 2007. A Brief History of Neoliberalism. New York: Oxford University Press.

HEYER, Judith, Pepe ROBERTS, and Gavin WILLIAMS (eds.). 1981. Rural Development in Tropical Africa. London and Basingstoke: Springer.

HILLMAN, Benjamin. 2003. "Opening up: The Politics of Poverty and Development in Rural China." Development Bulletin 61(May): 47-50

HILLMAN, Benjamin. 2010. "Factions and Spoils: Examining Political Behaviour within the Local State in China." The China Journal 64: 1-18.

HU, Zhanping, Qian Forrest ZHANG, and John A. DONALDSON. 2017. "Farmers' Cooperatives in China: A Typology of Fraud and Failure." The China Journal 78: 1-24.

KUHN, Lena, Stephan BROSIG, and Linxiu ZHANG. 2016. "The Brink of Poverty: Implementation of a Social Assistance Programme in Rural China." Journal of Current Chinese Affairs 45(1): 75-108.

LASSWELL, Harold Dwight. [1936] 1950. Politics: Who Gets What, When, How. New York: P. Smith.

LEUNG, Joe C.B., and Richard C. NANN. 1995. Authority and Benevolence: Social Welfare in China. Hong Kong: Chinese University Press.

LI, Shi 李實, and Sui YANG 楊穗. 2009. “中國城鎮低保政策對收入分 配和貧困的影響作用” (Zhongguo chengzhen dibao zhengce dui shouru fenpei he pinkun de yingxiang zuoyong, Impacts of China's urban dibao policy on income distribution and poverty). 中國人口科學 (Zhongguo renkou kexue Chinese Population Studies) 5: 11-20.
LI, Shi, Chuliang LUO, and Terry SICULAR. 2011. Overview: Income Inequality and Poverty in China, 2002-2007. No. 2011-10. CIBC Working Paper.

NGOK, Kin-Lun, and Genghua HUANG. 2014. "Policy Paradigm Shift and the Changing Role of the State: The Development of Social Policy in China since 2003." Social policy and society 13(2): 251-61.

PAN, Yi. 2017. Rural Welfare in China. New York: Springer International Publishing.

PARK, Albert, Sangui WANG, and Guobao WU. 2002. "Regional Poverty Targeting in China." Journal of Public Economics 86(1): 123-53.

ROGERS, Sarah. 2014. "Betting on the Strong: Local Government Resource Allocation in China's Poverty Counties." Journal of rural studies 36: 197-206.

SHI, Shih-Jiunn. 2012. "Towards Inclusive Social Citizenship? Rethinking China's Social Security in the Trend Towards Urban-Rural Harmonisation." Journal of Social Policy 41(4): 789-810.

SOLINGER, Dorothy J. 2017. "Manipulating China's 'Minimum Livelihood Guarantee'. Political Shifts in a Program for the Poor in the Period of Xi jinping." China Perspectives 2(110): 47-57.

SOSS, Joe, Richard C. FORDING, and Sanford F. SCHRAM. 2009. "Governing the Poor: The Rise of the Neoliberal Paternalist State." Annual Meeting of the American Political Science Association, Toronto.

UNGER, Jonathan. 2003 "Entrenching Poverty: The Drawbacks of the Chinese Government's Policy Programs." Development Bulletin 61(May): 29-33

WU, Guobao. 1997. "Policy on Subsidised Poverty Loans in China: A discussion." Beijing, Rural Development Institute, Chinese Academy of Social Sciences.

YAN, Kun. 2016. Poverty Alleviation in China. New York and London: Springer-Verlag Berlin An.

YANG, Lichao, Robert WALKER, and Jian XIE. 2019. "Shame, Face and Social Relations in Northern China: Ramifications for Social Assistance Provision." The China Quarterly (October): 1-21. https://doi.org/10.1017/ S0305741019001255. 